\title{
TRANSCENDING THE 'TRAGIC MULATTO': THE INTERSECTION OF BLACK AND INDIAN HERITAGE IN CONTEMPORARY LITERATURE
}

\author{
Lindsey Claire Smith \\ Minnesota State University
}

The supposed plight of multi-racial persons is widely depicted in modern American literature, including the works of William Faulkner, whose stories follow the lives of multi-racial characters such as Joe Christmas and Sam Fathers, who, reflecting characteristics of "tragic mulatto" figures, search for acceptance in a racially polarized Mississippi society. Yet more contemporary literature, including works by Michael Dorris, Leslie Marmon Silko, Toni Morrison, and Clarence Major, reference the historical relationship between African Americans and American Indians, featuring multi-racial characters that more successfully fit the fabric of current American culture than do more "traditional" works such as Faulkner's. While an outdated black-white binary still lingers in American perceptions of race, increasingly, racial identity is now informed by self-identification, community recognition, and acculturation. As a result, black and Indian characters, as well as multi-racial authors, provide varied and insightful glimpses into the complexity of America's racial landscape.

The historic connection between African Americans and Native Americans has long been recognized by members of both groups 


\section{Ethnic Studies Review Volume 26: 1}

and has recently attracted greater attention by scholars. Historians such as William Loren Katz and Jack D. Forbes have rightly called for further study of this important relationship, emphasizing the inaccuracy of a continued focus on a blackwhite nexus in discussions of race in America. Both Katz and Forbes have pointed toward contact between Africans and Natives of the Americas prior to the American colonial period, shared experiences of slavery at the hands of both Europeans and Natives, ${ }^{1}$ the development of unique black Indian communities on the American frontier, and cooperation in revolts against European control as evidence of cultural affinity, amalgamation, ${ }^{2}$ and shared senses of purpose among the two peoples, the basis of a kinship that endures in modern times. Echoing Edward Said's binary of "Orient" v. "Occident," widespread recognition of the rich interplay and exchange among various racial or ethnic groups in America nonetheless has historically been suppressed, as people with complex and dynamic heritages have been relegated into categories of "white" and "non-white." Forbes asserts:

The ancestry of many modern-day Americans, whether of 'black' or 'Indian' appearance, is often (or usually) quite complex indeed. It is sad that many such persons have been forced by racism into arbitrary categories which tend to render their ethnic heritage simple rather than complex. It is now one of the principal tasks of scholarship to replace the shallow one-dimensional images of non-whites with more accurate multi-dimensional portraits. (271)

Not surprisingly, one-dimensional, images of non-whites have been standard in American literature, particularly Southern literature, in which race is most often the dominant theme. In the Modern period, reflecting the Jim Crow era's stringent enforcement of black and white as opposite, polarized racial demarcations, this black-white binary is present in the works of both white and black writers, authors who situate themselves at either racial extreme. Among many examples are Richard Wright and William Faulkner, each of whom writes from his involvement in the horrific brutality that has characterized American, and particularly Southern, racism, but each writing 
from an opposite vantage point: Wright reflects his desperation and the physical and psychological hunger imposed by inescapable white oppression in works such as Black Boy, Native Son, and Twelve Million Black Voices, and Faulkner reports the guilt and sense of implicit responsibility for that oppression against Blacks in works such as Go Down, Moses, Light in August, and The Sound and The Fury.

Faulkner's works in particular impose this black-white polarity even in their portrayal of characters of mixed racial heritage, emphasizing that the two extremes cannot be reconciled. Characters such as Joe Christmas face a dual black and white racial background, struggling to develop an acceptable sense of identity in the face of a racially polarized Mississippi society. In Faulkner's works this existence is ultimately one of tragedy; Joe Christmas becomes a murderer largely due to this conflicted identity, epitomizing the stock figure of a "tragic mulatto." 3 Even Faulkner's "wilderness" stories, which feature Sam Fathers, a black Indian character, reflect a limiting focus on black-white polarity. Fathers, who is a lone practitioner of disappearing tribal ways, is somewhat alienated from the black community with which he is associated as well as from the white culture that is quickly encroaching upon the wilderness and thereby his traditional way of life. While Fathers is clearly a more positive character than Joe Christmas, he is nonetheless an anomaly and a figure for whom there is no longer a place in Mississippi society, despite the wisdom he imparts to young lke. Faulkner's characters of black and Indian ancestry, much like tragic mulattos, are objects of pity, with no legitimate place in either culture and thereby no real place in American society.

While it is to works by authors such as Faulkner and Wright that we often turn when we investigate literary presentations of race, these texts, while obviously critical to a mapping of the history of American race relations, should not continue to stand as the only reference points for writing about race. More recent work has pointed to a multi-racial reality, particularly the strong connection between Native Americans and African Americans, which has always permeated American society. Importantly, more contemporary texts by African American authors such as Toni Morrison, Clarence Major, and Alice Walker and Native 


\section{Ethnic Studies Review Volume 26: 1}

American writers such as Leslie Marmon Silko and Michael Dorris contain black Indian characters who reflect a shift from a "tragic mulatto" model to one in which a varied racial background is a source of pride and key to contemporary definitions of heritage. These contemporary models are informed by the authors' notions of their own racial backgrounds and senses of ethnic heritage.

Toni Morrison's patterning of "rememory" is widely acclaimed and central to her literary explorations of African American experiences. Importantly, this process involves acknowledgement of Indians as involved in these African American experiences. In Morrison's Beloved (1987), Paul D's escape to the North is facilitated by his stay in a camp of Cherokees who have resisted removal to Oklahoma. Coping with the devastation of disease and broken promises, the Cherokees are a solace to Paul D and his fellow prisoners from Alfred, Georgia, and one of the tribal members offers direction and almost prophetic reassurance to Paul D when he decides to head north: "That way. Follow the tree flowers. Only the tree flowers. As they go, you go. You will be where you want to be when they are gone" (112). Later, Paul D expresses his jealousy of four families of slaves who have remained together for years and have many racial backgrounds, including white, black, and Indian: "He watched them with awe and envy, and each time he discovered large families of black people he made them identify over and over who each was, what relation, who, in fact, belonged to who" (219). Paul D thereby reflects his own longing for a sense of family lineage, of heritage, and ultimately of community, which is not represented as "purely" African. Considering Morrison's presentation of this multi-racial alliance, her dedication, "sixty million and more," takes on another nuance. Not only does the text explore the "rememory" of sixty million enslaved Africans but also the oppression of Native Americans, the disruption of families, and the potential for community that slavery deposed.

Similar to Paul D's longing for a sense of heritage, Milkman also embarks on a journey to retrace the origins of his family in Morrison's Song of Solomon (1977). Milkman's travel from Detroit to Shalimar, Virginia, leads him to a discovery that his 
great-grandmother, Heddy, and grandmother, Singing Bird, were Indians and that his great-grandfather, Solomon, was a "flying African" who leaped back to Africa. After listening to local children chant Pilate's song, which tells the story of his family, and learning more about his background from his cousin Susan Byrd, Milkman is invigorated: "He was grinning. His eyes were shining. He was as eager and happy as he had ever been in his life" (304). On his way back to Detroit, Milkman is newly appreciative of the importance of his history, which he recognizes in Indian geographical names:

How many dead lives and fading memories were buried in and beneath the names of the places in this country. Names that had meaning. No wonder Pilate put hers in her ear. When you know your name, you should hang onto it, for unless it is noted down and remembered, it will die when you do. (329)

As in Beloved, Morrison depicts the process of rememory as inclusive of Native Americans, who shared families and often similar circumstances as African Americans.

Clarence Major's works also contain references to Indians, reflecting his own sense of varied heritage. In Such Was the Season (1987), Major's novel about a young man's reconnection to his familial roots in Atlanta, Aunt Eliza's recollection of her grandfather's Cherokee roots is key to her sense of the importance of homecoming, a value that propels her excitement at the arrival of Juneboy. Highlighting cooperation among Native and African Americans, Eliza remembers her grandfather, Olaudah Equiano Sommer ("Olay"), emphasizing the pride that Olay felt for his Cherokee heritage, particularly for his father, Grandpoppa, "an important man in the Cherokee Nation, who helped collect money to send colored families to Liberia" (4). Eliza recounts her favorite story about Grandpoppa, which describes his handcrafted wooden bird's ability to grant wishes. Frustrated that his request to the bird for the best of everything for the Cherokee Nation has seemingly gone unfulfilled, Grandpoppa goes to the bird and has the following experience:

The bird laughed and said change was everywhere, change for the better, there in the Cherokee Nation, and that he only had to learn how to see it. The bird told 


\section{Ethnic Studies Review Volume 26: 1}

Grandpoppa to go on back and try again. This time he began to notice how peoples was smiling and speaking kindly to each other and how even the little bitty children wont fighting over toys or nothing. The mommas making corn mush looked happy and the boys going out for the rabbit hunt looked just as happy. This noticing that Grandpoppa was doing went on for days, and before long he started believing the bird's magic had worked. (4-5)

Citing what she perceives to be Native American wisdom, Eliza associates this story with the value that she places on her own family:

I member being struck by that story that I dreamed about it over and over for a long time. So homecoming was a time of happiness, storytelling, a time when we all come together and membered we was family and tried to love each other, even if we didn't always do it so well (5).

In addition to her application of the values espoused in her greatgrandfather's Cherokee community to her perception of her present-day family, Eliza also finds personal relevance in a television report about Cherokee history. She observes,

He said that in 1715 there was a war called the

Yamasee war. In that war the white mens got a whole bunch of black mens to help them invade the Cherokees but the black mens stayed on even after the invasion and become part of the Cherokee Nation. They settled down and married Cherokee womens. . .And when the Cherokee come just a fighting the Creeks, the black mens fought right along with the Cherokee mens. The white mens couldn't understand why the black mens had stayed; so pretty soon the white mens stopped taking slaves to fight the Indians. I thought all of that was pretty interesting stuff. (108)

Eliza clearly finds personal relevance in this description of the historical alliance between Blacks and Indians, identifying with the blending of cultures indicated. Rather than finding her dual heritage to be confusing or alienating, she recognizes it as valuable to her own sense of empowerment and accentuates herself 
as a product of union between blacks and Cherokees, a union that has succeeded somewhat in fighting oppression. It is important to note, however, that Eliza's Indian heritage does not preclude her from firm grounding in the black community. Like her father, who "always passed for colored anyways cause that's the way he thought of hisself" (145), Eliza interacts primarily with black friends and family rather than with Cherokees. But importantly, Eliza's sense of identity is not merely tied to her skin color; her sense of ethnicity encompasses both parts of her family history.

Like Eliza, Clarence Major identifies himself as having both Indian and black heritage, and Such Was the Season thus reflects to a certain degree his own assertion of this dual racial background. As he explains in his autobiographical essay, "Licking Stamps, Taking Chances," Major was inspired to write the novel when he briefly served as writer-in-residence at Albany State College in Georgia in 1982 and had the chance to visit with his relatives in Atlanta, much as Juneboy does in the novel. He explains, "the novel ... had been coming for a long time, especially out of the voices I grew up listening to in the South and in the North" (197). Major's recognition of Indian heritage is more explicit in the "Introductory Note" of his poetry collection, Some Observations of a Stranger at Zuni in the Latter Part of the Century (1989):

These poems were inspired by spending time at Zuni and by living with the spirit and history of the Zunis and with the spirits of Southwestern Indians. They also, in a way, come out of my memory of my grandparents telling of the Indians among our own ancestors in the Southeast.

Major also writes of Native Americans in his metafictional works, My Amputations (1986) and Painted Turtle: Woman with Guitar (1988), which both follow the life of a Navajo guitar player. Major thus transcends the black-white paradigm in these works and achieves what Bernard Bell calls "transracial, transcultural, expressionistic narratives that thematize a self-reflexive process of creation of a dynamic, multifaceted self and art" (6). Underscoring this multi-faceted self, Major states in his introduction to the short story collection, Calling the Wind, "The 


\section{Ethnic Studies Review Volume 26: 1}

American presence is so varied and so complex that exchange and conflict between the black image and the white image tend absurdly to diminish the richness of a network of ethnic cultures that truly is the American human landscape" (xviii). Major thus navigates the American landscape more fully than many of his literary predecessors and contemporaries through his recognition of race as more than simply black or white.

Similarly, Alice Walker's novels and essays contain a significant Indian presence, which comes out in part because of her own multi-ethnic identity. Walker's Meridian (1976) begins with an epigraph taken from John Neihardt's translation of Black Elk Speaks:

I did not know then how much was ended. When I look back now . . . I can still see the butchered women and children lying heaped and scattered all along the crooked gulch as plain as when I saw them with eyes still young. And I can see that something else died there in the bloody mud, and was buried in the blizzard. A people's dream died there. It was a beautiful dream . . . the nation's hoop is broken and scattered. There is no center any longer, and the sacred tree is dead.

As Anne Downey has argued, the events in Walker's text parallel Black Elk's words, conflating the "spiritual journeys" of both Black Elk and Meridian (37). Like Black Elk's mourning for the death of his people, Meridian is acutely aware of widespread death and dehumanization that has resulted from slavery and segregation, which is vividly apparent to her in the life of Louvinie, the enslaved woman of the Saxon Plantation whose tongue was cut out and buried under a large magnolia tree in the middle of the Saxon College campus. For Meridian, the Sojourner tree, which has grown immensely and taken on magical qualities, is a revered emblem. Like the sacred tree that Black Elk speaks of, the Sojourner tree dies, sawed down by rioting students, signifying that like Black Elk's people, Meridian's community is broken.

Meridian mirrors Black Elk's spiritual experience of his people's tragedy chiefly through Native American mysticism. At a young age, she is impressed and initially frightened by her 
father's fascination with and sorrow for the Indians of Georgia, as he frequently argues with her mother about the continued relevance of the Indian experience and keeps a room full of books about and photographs of Indians. Meridian later learns from a conversation between her parents that her father's land rests on the Sacred Serpent, an Indian burial mound with mystical significance. According to a story that has been passed down to Meridian, her father's grandmother, Feather Mae, had a transformative experience at the Sacred Serpent, which caused her to renounce Christianity and embrace "the experience of physical ecstasy" (57), prompting her to walk around nude and worship the sun toward the end of her life. Meridian seeks to better understand this mysticism by going to the Sacred Serpent herself, watching her father, and entering the hallowed area:

She was a dot, a speck in creation, alone and hidden. It was as if the walls of the earth that enclosed her rushed outward, leveling themselves at a dizzying rate, and then spinning wildly, lifting her out of her body and giving her the feeling of flying. . . . When she came back to her body - and she felt sure she had left it-her eyes were stretched wide open, and they were dry, because she found herself staring directly into the sun. Her father said the Indians had constructed the coil in the Serpent's tail in order to give the living a sensation similar to that of dying: the body seemed to drop away, and only the spirit lived, set free in the world.

But she was not convinced. It seemed to her that it was a way the living sought to expand the consciousness of being alive, where the ground about them was filled with the dead. . . . Their secret: that they both shared the peculiar madness of her great-grandmother. It sent them brooding at times over the meaning of this. At other times they rejoiced over so tangible a connection to the past. (58)

From this spiritual initiation, which resembles Black Elk's vision that began his role as a holy man, Meridian begins her role as a holy woman, which drives her work for Civil Rights and for stronger communities. As Joseph Brown explains, Meridian "fashions herself not into an authentic witness, but into the very 


\section{Ethnic Studies Review Volume 26: 1}

presence of God, a presence that defies all telling" (312), and as the Sojourner has been destroyed, "she must take on the name and responsibility of the tree itself" (315). Significantly, Meridian's calling comes about not through her time with other black civil rights workers but through a sense of solidarity and identification with Native Americans, as she actually becomes somewhat of a mystic. In this way, though Meridian does not have Native American blood lineage, she is both Native and African in her sense of identification with both cultures, and this duality fuels her work to mend the "broken hoop" of her people.

Walker's novel, The Temple of My Familiar (1989), further develops this theme of alliance between blacks and Indians, specifically emphasizing the cultural and spiritual links between the two peoples. The major black Indian characters, Carlotta and Arveyda, are drawn together by their mutual embodiment of many cultures, including Arveyda's African American and Native American ancestry and Carlotta's African and Native South American ancestry. As their relationship proceeds, Carlotta enjoys and is able to identify with the multiple cultures of San Francisco that Arveyda introduces to her, and the couple's intimacy is accented by their sharing of multiple cultures rather than identification with one particular race or ethnicity. This multicultural alliance weathers even Arveyda's affair with Carlotta's mother, Zede, who develops a bond with Arveyda because of his similarity to her African lover, Jesus, who was enslaved in South America and murdered by Europeans. Significantly, Carlotta's reconciliation with her mother is affected by her care for the three precious stones given to Zede by Jesus' people, stones which are "the last remaining symbols of who they were in the world" (75).

Walker also highlights the co-mingling of African and Native cultures in her characterization of Lissie and Fanny, who both assert that they have lived several lives throughout time. Lissie explains that through a dream sequence, she recognizes a temple for "her familiar," her mythic fish/bird pet, her source of comfort during her dream memories in different worlds and unrecognizable centuries. She describes her temple as

very adobe or Southwestern-looking . . . It was painted

a rich dust coral and there were lots of designs-many, 
turquoise and deep blue, like Native American symbols for rain and storm-painted around the top. . . . The other thing my temple made me think of was the pyramids in Mexico, though I'm satisfied it wasn't made of stone but of painted mud. (116)

Notably, while Lissie strongly identifies herself as essentially a black woman, her source of spirituality is grounded in Native American imagery. Much like Meridian, she does not receive her strength for her "particular concentrated form of energy" (44) from an African tradition but rather from a mystic experience associated with aboriginal people of the Americas. Similarly, Fanny, a kindred spirit to Lissie, develops relationships with spirits from various historical periods. She becomes enchanted with Chief John Horse, a black Indian Seminole leader, and actually comes to embody him:

Fanny Nzingha found the spirit that possessed her first in herself. Then she found the historical personage who exemplified it. It gave her the strange aspect of a trinity-she, the spirit, the historical personage, all sitting across the table from you at once (185).

As Fanny explains, this falling in love with John Horse is empowering: "It becomes a light, and the light enters me, by osmosis, and a part of me that was not clear before is clarified. I radiate this expanded light. Happiness" (186). Fanny thereby finds her life to be enriched by actually internalizing this prominent Native American leader, as she does with spirits of other cultures. Overall, for Fanny and Walker's other multicultural characters, rather than finding this multiplicity confusing or ostracizing, it is the source of freedom.

In the same way that Clarence Major's work is informed by his own sense of multi-raciality, Walker's novels also reflect her strong identification as an embodiment of many racial heritages, and various cultures, particularly Native American cultures, inform her personal beliefs. Walker explains her dynamic sense of identity throughout her essay collection, Living by the Word (1988), in which she cites passages from Black Elk Speaks to frame her views on the environment and the importance of community, writes of her relationships with Native Americans such as Dennis Banks and Bill Wahpepah, and describes her own Native 


\section{Ethnic Studies Review Volume 26: 1}

ancestry. In her essay, "My Big Brother Bill," which she wrote in memory of Wahpepah, she cites James Mooney's description of the enslavement of Indians in all of the Southern colonies and the intermarriage of Blacks and Indians to emphasize the close relationship of the two peoples. She explains that during the eighties Indians were "very much in my consciousness" (43), as she confronted the presence of her Cherokee great-grandmother in her own lineage and was feeling drawn to Indian art, history, and folklore. Finally in the essay, she explains that her closeness to Bill can be explained by their "common intuitive knowledge that, in a sense, all indigenous peoples are, by their attachment to Mother Earth and experience with Wasichus, Conquistadors, and Afrikaners, one" (49). But Walker does not set up these indigenous peoples as in strict opposition to whites. In "In the Closet of the Soul," she explains, "We are black, yes, but we are 'white,' too, and we are red. To attempt to function as only one, when you are really two or three, leads, I believe, to psychic illness. .." (82). Similarly, in "On Seeing Red," she calls for a Whitman-esque celebration of diversity: "There are few 'white' people in America ... . and even fewer 'black' ones. . . . In our diversity we have been one people-just as the peoples of the world are one people-even when the most vicious laws of separation have forced us to believe we are not. I, too, sing America" (128). Therefore, like Major, Walker avoids limiting herself to a simple black-white opposition in her writings about race. Instead, like many of her fictional characters, she finds spiritual and intellectual strength in recognizing herself as a multicultural individual.

Likewise, Leslie Marmon Silko's Almanac of the Dead (1991) is a mammoth investigation of the intersection, confrontation, and shared experiences of Whites, Natives, and Blacks in the Americas. Clinton, a homeless Vietnam veteran raised in Houston, is driven in his beliefs and his self-understanding by his dual heritage. As Sharon Holland describes, he "give[s] voice to a crossblood existence denied to most in the retelling of colonial rule" (344). Silko writes:

blacks had been Americans for centuries now, and Clinton could feel the connection the people had, a connection so deep it ran in his blood. ... . He and the 


\section{Smith-Black and Indian Heritage}

rest of his family had been direct descendants of wealthy, slave-owning Cherokee Indians. . . . Clinton had liked to imagine these Cherokee ancestors of his, puffed up with their wealth of mansions, expensive educations, and white and black slaves. Oh, how 'good' they thought they were! (414-5)

Unlike the other black Indians heretofore discussed, Clinton avoids a strictly positive account of his Indian heritage. Although he is clearly proud of his Indian lineage, his understanding of this influence is not fuel for bragging, like it is for the old women in his family. Rather, his Cherokee ancestors project a valuable lesson:

So pride had gone before their fall. That was why a people had to know their history, even the embarrassments when bad judgment had got them slaughtered by the millions. Lampshades made out of Native Americans by the conquistadors; lampshades made out of Jews. Watch out African-Americans! The next lampshades could be you! (415)

In this way, Silko avoids romanticizing Indian ancestry as merely a connection to the past or a discovery of family secrets; instead, she gives Clinton's multiracial nature a clear purpose: it serves as his call to action.

Clinton is deeply interested in his genealogical routes not only to better understand himself but also to prompt others into an appreciation for their history and for the value that alliance between Blacks and Indians, and more broadly, "the poorest tribal people and survivors of European genocide" (749), holds in terms of activism, of "reclaim[ing] democracy from corruption at all levels" (410) and "show[ing] the remaining humans how all could share and live together on earth, ravished as she was" (749). To accomplish this, Clinton makes tapes that he plans to use for a radio broadcast that will be dedicated to the descendents of escaped African slaves and Native Carribbeans, whom he calls the first African-Native Americans. Included in his "Liberation Radio Broadcasts" are accounts of slave revolts in the Americas, during which Blacks and Indians cooperated to throw off European oppressors, revealing, "The spirits of Africa and the Americas are joined together in history, and on both continents 


\section{Ethnic Studies Review Volume 26: 1}

by the sacred gourd rattle" (429). Clinton thus recognizes that "If the people knew their history, they would realize they must rise up" (431).

Integral to this impetus to rise up is Clinton's belief in the close association between the African and Native American spirit worlds. He explains that escaped African slaves discovered hidden indigenous tribes and found that their African gods had found their way to America, cementing the peoples' inclusiveness of each other: "Right then the magic had happened: great American and African tribal cultures had come together to create a powerful consciousness with all people" (416). Clinton stresses that like the physical union of Natives and Africans, those of the spirit world are also united, so that the ancestors' spirits still surround black people in the United States. He expands this idea of intermingled spirit worlds in his conception of what he calls "Black Indians at Mardi Gras." Clinton characterizes these paraders who, apart from the middle class participants of the Negro Mardi Gras parade, celebrate the spirit of cooperation between African and Native Americans as black Indians who represent spirit figures, frightening Whites and creating a scene in which "No outsider knows where Africa ends or America begins" (421). This display is in microcosm what Clinton hopes will happen when Blacks realize that indeed their homeland is America, spiritually and historically: "All hell was going to break loose. The best was yet to come" (749).

Clinton's reconfiguration of accepted history in America echoes Silko's underlying objective throughout the novel. Shocking, confusing, and confronting her readers through this unique text, Silko challenges the dominant view of American culture, one that is often informed by the kind of polarization of black and white that disregards much of America's culture as well as its inhabitants. As Elizabeth McNeil suggests, "Silko deconstructs the dominant culture's anthropological view of Native America, past and present, as she prophecies a degenerating, yet transformative future for the global community" (1-2). Envisioning the world as a global community is indeed crucial to the text, as various characters, representing various cultures and ethnicities, are each connected to each other and must suffer, enjoy, or exploit the actions of others. As a result, the novel 
asserts an integrative view of race and culture similar to Walker's and Major's, reflecting on some level her own Laguna Pueblo and white background. Like those of the other writers, Silko's presentation of this multi-raciality is not the instigator of confusion or violence, as it is for Faulkner's tragic mulatto, but instead it is a means of confronting and rejecting a European hegemony and instigating a more just world.

Michael Dorris' A Yellow Raft on Blue Water (1987) and Cloud Chamber (1997), present Rayona, a black, Indian, and white adolescent, who also breaks Faulkner's tragic mulatto mold. In the earlier novel readers learn of Rayona's struggle to fit in on the Indian Reservation she lives on and in the white world that surrounds it. With her uncontrollable hair and darker skin Rayona is ostracized from the other, more "purely" Indian inhabitants of her native area as well as from white inhabitants of the nearby state park to which she runs away. Additionally, she struggles to be accepted by and to accommodate her Indian mother and aunt, Christine and Aunt Ida, as well as her black father, Elgin. Through Yellow Raft on Blue Water's three-section framework, which provides narrative voice for Rayona, Christine, and Aunt Ida, Dorris presents each character's experience of inter-racial contact, from Rayona's varied racial heritage to Christine's relationship with Elgin to Aunt Ida's relationship with Father Hurlburt. But while this novel introduces the implications of these cultural intersections from the Indian characters' points of view, it is in Dorris' later novel that the story expands and reaches its fruition.

In Cloud Chamber Dorris pursues more fully Rayona's genealogical lineage, including multiple narration from her Irish ancestors, which include Elgin's mother, as well as from Elgin, whose perception of his own multi-racial heritage as well as his relationship to Christine is illumined. Elgin's process of confronting his varied racial background involves his recognition of the world's estimation of race as merely black or white:

You broke the rules, Mom, and I'm exhibit 'A.' You and Aunt Edna and Grandma never made me feel bad about myself, but the world is bigger that this house and I've got to live in it as who I am. I've got to learn how. Not as a white boy who goes black on vacation. Not as a 


\section{Ethnic Studies Review Volume 26: 1}

Greek. Not as the band leader in the St. Patrick's Day parade. I'm who I say I am. I'm who you say I am. But I'm also who everybody else on earth says I am, and somehow that's got to add up to a single sum. (203) In addition to his black and white ancestry, Elgin also identifies as part Creek Indian, which he ponders as he enters into his relationship with Christine. Because of his relationship, Indian heritage is more to him than merely a link to a distant past or romanticized predecessors, and eventually it provides a better avenue for participating in Rayona's life. As Rayona explains before the naming ceremony:

$\mathrm{He}^{\prime} \mathrm{d}$ no doubt appear in some understated Indianthemed vest or belt buckle to advertise his right to be present, a little caption that communicated "Married In." There were times when Mom would have liked to add her own parentheses-Divorced Out-but in the end she forgave him ... . Dad was my link to Mom, the only other person besides me who could remember those rare and amazing times when the three of us were a family. And, to be honest, he was more than that, too. He was family. (272)

Ultimately, the single sum that Elgin is seeking takes shape in his daughter.

Rayona's naming ceremony is the culmination of her own process of seeking a single sum. After meeting and surviving a KFC nightmare with her white grandmother and great aunt, accepting more fully her father, coming to terms with her mother's legacy, and expressing her love for Aunt Ida, Rayona is able bridge successfully the many cultures, what she calls her "own personal ethnic rainbow coalition" (273), that shape her. Her summation of these many influences is emblematized in her acceptance of her great-great grandmother Rose's Irish cut-glass vase as well as her adoption of Rose's name at the ceremony, her receipt of an eagle feather and Pendleton blanket from her mother's friend Dayton, and her donning of the non-traditional dress that Aunt Ida fashions for her for the pow-wow:

when you start mixing up rawhide and satin and calico and tanned deerskin, when you make a red-and-black statement in a shawl and expect it to complement a 


\section{Smith-Black and Indian Heritage}

turquoise and magenta zigzag in a dress, when you sew snuff lid jingles and tiny cowbells to any square inch that isn't otherwise occupied with neon yarn fringe, when you interchange floral and geometric in the same beadwork pattern, when you simultaneously push the traditional and the fancy dance buttons, when you give equal nods to plains, woodland, southwest, and northwest coast design motifs and then throw in a little Dances with Wolves glitz to spice them up, you get . . . well, you get what I'm wearing. (305)

Rayona's making peace with her heritage is thereby finally and poignantly reflected in her statement, "There's room for everybody" (316).

Rayona's, and by implication Dorris', message at the conclusion of this novel is a bold one. While black Indians in other works are significant because of their connection to the past and embodiment of alliance against Europeans, Rayona is an acknowledgement that these cultures-white, black, and Indian-can coexist in the present. As Gordon Slethaug notes, "the second novel . . . suggest[s] that whites and blacks also share losses, and that racial groups can work together to ameliorate those losses and gain a new sense of community" (18). Dorris' projection of this ideal likely stems from his own embodiment of white and Native ancestry. As Thomas Matchie explains, Dorris' own Irish lineage and home place of Kentucky provides material for much of Cloud Chamber, and Dorris' Modoc ancestry, academic work in Native American studies, and marriage to Native author, Louis Erdrich, were widely recognized before his death. ${ }^{4}$ Through his works, then, Dorris is offering a contemporary view of multi-raciality in America that is somewhat more personal and somewhat less politicized than the views presented by other authors, yet this more personal view has nonetheless important political implications, suggesting that individuals cannot always be labeled as either white or "Other." While Rayona's life is certainly made difficult by racism, her integration of ostensibly opposing cultures is hopeful, even reassuring. But is it realistic? In an America still impeded by an obsession with black and white, how plausible are Rayona's personal fulfillment, Clinton's call to action, Fanny's and Lissie's entering the spirit 


\section{Ethnic Studies Review Volume 26: 1}

world, Meridian's transformation into a goddess, Eliza's veneration of homecoming, or Milkman's journey to Virginia?

In America's tableau of widely varying peoples and their histories, these portraits of multiracial individuals are certainly more realistic and of increasing value to our discussions of race in this country than the tragic mulatto model that has been a presence in those discussions throughout the twentieth century. Perhaps the most important reason for this shift is that in addition to America's growing racial and ethnic diversity, more Americans are identifying themselves as multi-racial. In the 2000 Census, when for the first time individuals were allowed to check more than one box to identify themselves racially, the results were as follows: $6,826,228$ Americans identified themselves as of two or more races. 5 Of those, $6,368,075$ were of two races, 410,285 were of three races, 38,408 were of four races, 8,637 were of five races, and 823 were of six races (Grieco and Cassidy 4-5). While these numbers provide no narrative of the lives behind them, they reflect the fact that given a situation in which respondents are free to present themselves racially in whatever manner they choose, almost seven million Americans made a deliberate decision to affirm a multiplicity in their racial identities rather than aligning themselves at either end of a black-white binary. As these Americans as well as the literary characters discussed reveal, while cross-cultural alliance often has empowered the oppressed against the dominant society, the dominant society is not always simply lined up in polar opposition to that alliance, as a "white-Other" polarity still excludes many individuals from embracing the entirety of their identities.

This is certainly not to say that living with a multi-racial identity is easy or that it frees one from racism, especially since the majority of Americans still identify themselves as of only one race. What it does mean is that the literary models we have traditionally used are not sufficient (and never really have been) to tell the whole story of race, and more specifically multi-raciality, in America. Moreover, just as Henry Louis Gates has interrogated "the ideas of difference inscribed in the trope of 'race" (6), the perspectives of those with multi-racial heritage challenge assumptions about racial difference, as they challenge abstract and arbitrary racial categorization. And just as Gates called for 
development out of the black tradition of criticism for African American literature, criticism of much contemporary American literature, as well as future literature that will no doubt reflect greater ethnic plurality, also will require new thinking about race, drawing on the historic and continued convergence of various peoples in America. ${ }^{6}$ As William S. Penn suggests, "a renewed diversity of imagination of thinking is something mixblood writers - whatever their backgrounds or disciplinesoffer postmodern America and Western culture" (3).

Ultimately, it is clear that while Faulkner's "tragic mulatto" model sheds light on our past and still influences American consciousness, contemporary perceptions of dual or multi-ethnicity have become much more dynamic. In the words of Rainier Spencer, "There is a vast difference between wondering whether one is black or white and questioning whether anyone really is" (127). As a result, black Indian characters, as well as multi-racial authors, provide varied and insightful glimpses into America's complex racial landscape. Rather than merely embodying tragedy, these figures encourage ever-greater recognition that our collective heritage cannot be seen only in black and white.

\section{NOTES}

1 The WPA Oklahoma Slave Narratives, edited by Lindsay T. and Julie P. Baker, offers fascinating portraits of the cultural exchange that accompanied African Americans' enslavement by members of the Five "Civilized" Tribes (excluding the Seminole tribe), including African Americans' adoption of Native cooking techniques and medicinal practices that endure among their descendents.

2 The Lumbee tribe of North Carolina is one Native American tribe that reflects the influence and integration of a range of cultures, including European and African American. The Lumbees' continued failure to attain federal recognition as a tribe reflects the way in which the United States has often refused to recognize the dynamic and unique nature of each Native American tribe. See Chapter Two, "We Ain't Got Feathers and Beads," of Fergus Bordewich's Killing the White Man's Indian: Reinventing Native Americans at the End of the Twentieth Century.

3 Significantly, Forbes reveals that the term "mulatto" referred to people of mixed African and Native American descent in the sixteenth century (181). Samuel Johnson's 1756 dictionary was the first instance of the 
Ethnic Studies Review Volume 26: 1

definition of "mulatto" as indicating black and white racial lineages (193).

${ }^{4}$ David T. McNab calls Dorris' Modoc ancestry into question in his article "Of Beads and a Crystal Vase: An Exploration of Language into Darkness, of Michael Dorris's The Broken Cord and Cloud Chamber." West Virginia University Philological Papers 47 (2001): 109-19.

${ }^{5}$ A staggering 1,082,683 respondents identified themselves as "White; American Indians and Alaska Native." Many, including Native American leaders, have called this number into question, as it's likely, in consideration of numbers compiled by tribes, that many of these individuals retain no tribal affiliation (either community recognition or tribal membership). Yet even if many of these individuals have no substantiated claim to Native heritage, it is nonetheless worthy of note that they do not see themselves as only white. Other numbers relevant to the discussion of Blacks and Indians are as follows: 784,764 respondents were "White; Black or African American," 182,494 were "Black or African American; American Indian and Alaska Native," and 112,207 were "White; Black or African American; American Indian and Alaska Native."

6 Bernadette Rigal-Cellard has discussed Louis Owens's integration of both Western and Native American literary traditions in his novel The Sharpest Sight (1992) as a "com[ing] to terms with the complexities of . multicultural legacies" (164). See Rigal-Cellard's "Western Literary Models and Their Native American Revisiting" in Native American Representations: First Encounters, Distorted Images, and Literary Appropriations. Ed. Gretchen M. Bataille. Lincoln, NE: University of Nebraska Press, 2001. 152-165.

\section{WORKS CITED}

Baker, Lindsay T. and Julie P. Baker, Eds. The WPA Oklahoma Slave Narratives. Norman, OK: University of Oklahoma Press, 1996.

Bell, Bernard. Introduction. Clarence Major and His Art. Ed. Bernard W. Bell. Chapel Hill, NC: University of North Carolina Press, 2001. 1-9.

Bordewich, Fergus M. Killing the White Man's Indian: Reinventing Native Americans at the End of the Twentieth Century. New York: Anchor, 1997.

Brown, Joseph. "'All Saints Should Walk Away': The Mystical Pilgrimage of Meridian." Callaloo 0.39 (Spring 1989): 310-20. 
Dorris, Michael. Cloud Chamber. New York: Simon \& Schuster, 1997.

---. A Yellow Raft on Blue Water. New York: Warner Books, 1987.

Downey, Anne. "'A Broken and Bloody Hoop': The Intertextuality of Black Elk Speaks and Alice Walker's Meridian. MELUS 19.3 (Fall 1994): $37-45$.

Forbes, Jack D. Africans and Native Americans: The Language of Race and the Evolution of Red-Black Peoples. Urbana, IL: University of Illinois Press, 1993.

Gates, Henry Louis Jr. "Writing 'Race' and the Difference It Makes." "Race," Writing, And Difference. Ed. Henry Louis Gates, Jr. Chicago: The University of Chicago Press, 1986.

Grieco, Elizabeth M. and Rachel C. Cassidy. "Overview of Race and Hispanic Origin." U.S. Census Bureau (March 2001): 4-5. Accessed 11 July 2002 from the World Wide Web: http://www.census.gov/population/www/cen2000/briefs.html

Holland, Sharon. "If You Know I Have a History, You Will Respect Me': A Perspective on Afro-Native American Literature." Callaloo 17.1 (Winter 1994): 334-50.

Katz, William Loren. Black Indians: A Hidden Heritage. New York: Ethrac Publications, 1986.

Major, Clarence. Ed. Calling the Wind: Twentieth Century AfricanAmerican Short Stories. New York: Harper Collins, 1993.

---. "Licking Stamps, Taking Chances." Contemporary Authors Autobiography Series. Ed. Adele Sarkissian. Vol. 6. Detroit: Gale Research, 1988. 175-204.

---. My Amputations. New York: The Fiction Collective, 1986.

---. Painted Turtle: Woman with Guitar. Los Angeles: Sun \& Moon Press, 1988.

---. Some Observations of a Stranger at Zuni in the Latter Part of the Century. Los Angeles: Sun \& Moon Press, 1989.

---. Such Was the Season. San Francisco: Mercury House, 1987.

Matchie, Thomas. "Posttribal Sunshine in Michael Dorris' Cloud Chamber." North Dakota Quarterly 66.3 (Summer 1999): 33-41.

McNeil, Elizabeth. "Leslie Marmon Silko's Comic 'World of the 


\section{Ethnic Studies Review Volume 26: 1}

Different': Almanac Of the Dead as Cross-Cultural Trickster Discourse." Studies in American Humor 3.5 (1998): 1-33.

Morrison, Toni. Beloved. New York: Penguin, 1987.

---. Song of Solomon. New York: Penguin, 1977.

Penn, William S. Introduction. As We Are Now: Mixblood Essays on Race and Identity. Ed. William S. Penn. Berkeley: University of California Press, 1997.

Rigal-Cellard, Bernadette. "Western Literary Models and Their Native American Revisiting." Native American Representations: First Encounters, Distorted Images, Literary Appropriations. Ed. Gretchen M. Bataille. Lincoln, NE: University of Nebraska Press, 2001. 152-165.

Said, Edward. Orientalism. New York: Random House, 1978.

Silko, Leslie Marmon. Almanac of the Dead. New York: Penguin, 1991.

Sleuthaug, Gordon E. "Multivocal Narration and Cultural Negotiation: Dorris's A Yellow Raft in Blue Water and Cloud Chamber." Studies in American Indian Literature 8.1 (Spring 1996): 13-29.

Spencer, Rainier. "Race and Mixed-Race: A Personal Tour." As We Are Now: Mixblood Essays on Race and Identity. Ed. William S. Penn. Berkeley: University of California Press, 1997. 126-139.

Walker, Alice. Living by the Word: Selected Writings, 1973-1987. Harcourt Brace Jovanovich: San Diego, 1988.

---. Meridian. Simon and Schuster: New York, 1976.

---. The Temple of My Familiar. Simon and Schuster: New York, 1989. 